\title{
HAS COVID-19 PANDEMIC AFFECTED FIRM PROFITABILITY? DYNAMIC PANEL DATA ANALYSIS OF BIST FIRMS USING DUPONT IDENTITY COMPONENTS
}

\author{
DOI: 10.17261/Pressacademia.2021.1484 \\ PAP- V.14-2021(10)-p.42-47
}

\section{Dilek Demirhan ${ }^{1}$, Atakan Sakin²}

${ }^{1}$ Ege University, Department of Business Administration, Izmir, Turkey. dilek.demirhan@ege.edu.tr, ORCID: 0000-0001-6507-2927

${ }^{2}$ Ege University, MBA Programme, Izmir, Turkey. atakansakin@icloud.com, ORCID: 0000-0003-4554-5840

\section{To cite this document}

Demirhan, D., Sakin, A., (2021). Has Covid-19 pandemic affected firm profitability? Dynamic panel data analysis of BIST firms using Dupont identity components. PressAcademia Procedia (PAP), 14, 42-47.

Permanent link to this document: http://doi.org/10.17261/Pressacademia.2021.1484

Copyright: Published by PressAcademia and limited licensed re-use rights only.

\section{ABSTRACT}

Purpose- The purpose of this study is to analyse the effects of COVID-19 pandemic on listed firms' profitability ratios. Du Pont Identity, which relates the Return on Equity (ROE) to Total Asset Turnover (TAT), Net Profit Margin (NPM) and Equity Multiplier (EM), is a widely known tool to analyse the firms' profitability. In this regard, the components of this identity are used in our study as variables of dynamic panel data model.

Methodology- Arellano-Bond dynamic panel-data estimation is used in the study in order to take the persistence of firm profits and endogeneity of independent variables into account. Sample of the study consists manufacturing and non-manufacturing firms, except financial firms such as holdings, banks, investment trusts and etc., listed in Borsa Istanbul. Total of 153 firms, whose data can be collected fully between the $3^{\text {rd }}$ quarter of 2017 and $2^{\text {nd }}$ quarter of 2021, are included in the sample. Three models are tested, in which ROE, Return on Assets (ROA) and NPM are dependent variables in different models. Dummy variable (COVID), taking the value of 0 between $3^{\text {rd }}$ quarter of 2017 and $1^{\text {st }}$ quarter of 2020, and value of 1 between $2^{\text {nd }}$ quarter of 2020 and $2^{\text {nd }}$ quarter of 2021 is used to investigate the effects of COVID on ROE, ROA and NPM.

Findings- Models are first tested in sample of all firms, then sample is splitted into manufacturing firms and non-manufacturing firms to be able to compare effects of COVID in different industries. According to the findings of models tested in all firms sample, dummy variable representing COVID affects ROE positively, but it has negative effects on ROA and NPM, where negative effect on NPM is higher. In sample of manufacturing firms, findings of the models show that COVID variable has negative effects on ROE and ROA, but surprisingly a positive effect on NPM. Differently in sample of non-manufacturing firms, analysis results reveal negative effect of COVID on NPM and ROA, whereas positive effect on ROE.

Conclusion- Findings of the study show that COVID has affected profitability measures in a different way. Moreover, effects on manufacturing and non-manufacturing firms are also different. NPM of manufacturing firms seems to be affected positively, which may be an indicator that manufacturing firms have been managing the costs more efficiently during pandemic period. Negative effects on ROE and ROA may be the result of inefficient management of assets and equity. Models tested in sample of non-manufacturing firms reveal a negative effect of COVID on NPM. Lockdowns during the pandemic period made it difficult to manage the costs for non-manufacturing firms. Although manufacturing firms were able to continue their operations during lockdowns, it was impossible especially for service industry. However, positive effect on ROE may be the result of efficient management of equity by non-manufactoring firms during pandemic period.

Keywords: COVID-19, Du Pont Identity, profitability, dynamic panel, Borsa Istanbul

JEL Codes: G30, G32, L25

\section{INTRODUCTION}

COVID-19 pandemic has been affecting all areas of our lives all over the globe since the first quarter of 2020. The effects of the pandemic has triggered a significant economic crisis resulting in a global economic shock. Measures and restrictions such as quarantines, travel bans and restrictions, social distance enforcemenst and lockdowns were imposed by governments to get pandemic under control. These measures have given rise to disruptions in economic and social activities, which in turn affected both financial and non-financial performance indicators of businesses. By the last quarter of 2021, those effects became more observable, since relevant data has started to be accumulated. 
One of the most considered performance indicator for firms is profitability and the purpose of this study is to analyse the effects of COVID19 pandemic on listed firms' profitability ratios. Manufacturing and non-manufacturing firms listed in Borsa Istanbul are selected as a sample of the study. Banks, holdings, investment trusts and other financial corporations are excluded from the sample since they have different operational and financial structures. Total of 153 firms, whose data can be collected fully between the $3^{\text {rd }}$ quarter of 2017 and $2^{\text {nd }}$ quarter of 2021, are included in the sample.To investigate the sample firms' profitability during the COVID period the components of Du Pont Identity are taken as variables in dynamic panel data models. Du Pont Identity, is a widely known tool to analyse firms' profitability and it relates the Return on Equity (ROE) to Total Asset Turnover (TAT), Net Profit Margin (NPM) and Equity Multiplier (EM). Three models are tested, in which ROE, Return on Assets (ROA) and NPM are dependent variables in different models. Dummy variable (COVID), taking the value of 0 between $3^{\text {rd }}$ quarter of 2017 and $1^{\text {st }}$ quarter of 2020, and value of 1 between $2^{\text {nd }}$ quarter of 2020 and $2^{\text {nd }}$ quarter of 2021 is used to investigate the effects of COVID on ROE, ROA and NPM. Literature review is reported before the explanation of the data and methodology of the study. Next findings are presented followed by the conclusion part.

\section{LITERATURE REVIEW}

Effects of COVID-19 pandemic on economic activities, financial markets and businesses have been investigated by different researchers. Economic effects have been analysed on the grounds of labor markets, sectoral supply and demand shocks, mobility and consumption patterns, and business failures (Gourinchas et al.,2021). Stock market reactions to pandemic restrictions have also been analysed by using different indices or individual stock prices. For example, Ren et al. (2021) focused on provincial equity market performance during the spread of COVID-19 in China, by quantifying the impact of regional COVID-19 outbreaks in thirty-one provinces on the stock returns of local listed firms. Their findings revealed that effects of the pandemic created a significant cross-sectional return difference in terms of firm geographical location and outbreak timings. (Ren et al., 2021). Individual stock returns were also investigated by different researchers. Song et al.(2021) focused on the stock returns of US restaurant firms. They found that stock returns of restaurant firms with past characteristics of larger size, more leverage, more cash flows, less ROA, and more internationalization were affected less than otherwise similar firms (Song et al., 2021).

Business activities have also been influenced during the pandemic period and several studies were conducted to examine the impact of the pandemic on businesses. By using data of 188 non-financial firms from the Malaysian market for the years 2019-2020, Khatib \& Nour (2021) found that COVID-19 influenced various firm characteristics such as firm performance, governance structure, dividend, liquidity, and leverage level, however their results did not reveal a significant difference between prior and post COVID-19 pandemic. Hu\&Zhang (2021) constructed a large international sample of 16,148 firms from 107 countries and they examined whether ROA of the firms are affected by the cumulative or new cases reported by the jurisdictions. Their findings revealed that ROA and the number of COVID-19 cases were negatively correlated. Moreover, they found that countries with higher healthcare expenditure were better at struggling with the negative effects of the pandemic. In addition, businesses operating in countries with better financial development were affected less negatively (Hu \& Zhang, 2021). A survey study was conducted in China to examine the effect of the pandemic on SME's business norms and performance. As a result of the Structural Equation Modelling technique, Chinese firms' innovative activities, profitabilities and stakeholder satisfactions were found to be influenced significantly by COVID-19 pandemic (Sun et al., 2021). Liquidity is also important for firm performance and Amnim et al. (2021) analysed the impact of the pandemic on Nigerian firms' liquidity and profitability. Their findings showed that liquidity ratio and ROE of the sample firms were affected significantly during the COVID-19 period largely because of the government-imposed lockdowns. They recommended governments to strengthen the support for local provision of raw materials, so that businesses could attain input for manufacuting more easily enabling them to maintain optimal liquidity and improved profitability (Amnim et al., 2021).

Turkish firms listed in Borsa Istanbul were also investigated for the effects of COVID-19 pandemic. Durak\&Comlekci (2021) classified firms in the BIST 100 index through selected financial ratios by using cluster analysis to compare their pre-COVID-19 and the COVID-19 period situations. They obtained seven clusters in both the pre-COVID-19 and the COVID-19 period, however the number of firms and firms forming the clusters were different. Moreover, their findings showed that firms with the highest rate of profitability per share, net profit margin and asset profitability were operating in the health, pharmaceutical, communication and food sectors (Durak \& Comlekci, 2021). Yucel\&Durak (2021) compared the financial ratios of BIST manufacturing firms before (first 6 months of 2019) and during (first 6 months of 2020) pandemic period. According to their findings, pandemic negatively affected the Main Metal Industry and the Textile, Clothing and Leather Industry. In addition, the ratios of firms producing products such as pharmaceuticals, disinfectants, basic food and packaging were positively affected, where as the other firms' ratios were affected negatively (Yucel \& Durak, 2021). Kilinc\&Calis (2021) examined the effects of the Covid-19 on BIST-Food\&Beverage Industry firms by using panel data analysis. They found that market value of sample firms were positively affected during the pandemic period (Kilinc \& Calis, 2021). Ozcan (2021) used Data Envelopment Analysis (DEA) and Tobin-q ratio to measure the activities of BIST-Tourism\& Transportation Industry firms before and during COVID-19 period. Findings of DEA revealed negative effect of COVID on sample firms, but according to Tobin-q the impact is negative (Ozcan, 2021). Content analysis was used by Ozata Canli \& Ozdemir (2021) to compare financial performances and industry-specific indicators of airline firms listed in BIST-100 index. The results revealed negative effect of the pandemic on Turkish air transport (Ozata Canli \& Ozdemir, 2021). Kutay \& Tektufekci (2021) also used content analysis and detected negative impact of the pandemic period on profitability ratios of firms listed in BIST Tourism Index. Bulut \& Gurbuz (2021) analysed the effect of COVID-19 on financial ratios of BIST- Corporate Governance Index firms by using independent sample t-tests. They found significant differences for all financial ratios between the pre-pandemic period and pandemic period.

Thus, prior studies in the literature revealed that COVID-19 pandemic had significant effects on businesses. However, the magnitude and direction of the effects may be different according to the country, industry and scale of the businesses. 


\section{DATA AND METHODOLOGY}

Arellano-Bond dynamic panel-data estimation is used in the study in order to take the persistence of firm profits and endogeneity of independent variables into account. Sample of the study consists manufacturing and non-manufacturing firms, except financial firms such as holdings, banks, investment trusts and etc., listed in Borsa Istanbul. Total of 153 firms, whose data can be collected fully between the $3^{\text {rd }}$ quarter of 2017 and $2^{\text {nd }}$ quarter of 2021, are included in the sample. Three models are tested, in which ROE, ROA and NPM are dependent variables in different models. Data was collected from quarterly financial statements of sample firms by using Datastream. Variables used in three models are determined based on Du Pont Identity ${ }^{1}$, which is a popular financial analysis and control tool in managerial finance. The variables of the models are explained in Table 1.

Table 1: Variable of the Models

\begin{tabular}{|c|c|c|}
\hline Model & Dependent Variables & Independent Variables \\
\hline 1 & ROE: Net Income/Total Equity & $\begin{array}{l}\text { - COVID: Dummy variable taking value } 0 \text { between } 3^{\text {rd }} \text { quarter of } 201 \text { and } 1^{\text {st }} \text { quarter of 2020, } \\
\text { and value of } 1 \text { between } 2^{\text {nd }} \text { quarter of } 2020 \text { and } 2^{\text {nd }} \text { quarter of } 2021 . \\
\text { - Size: Natural Logarithm of Total Assets } \\
\text { - TAT: Net Sales/Total Assets (endogenous) } \\
\text { - NPM: Net Income/Net Sales (endogenous) } \\
\text { - EM: Total Assets/Total Equity (endogenous) }\end{array}$ \\
\hline 2 & ROA: Net Income/Total Assets & $\begin{array}{l}\text { - COVID: Dummy variable taking value } 0 \text { between } 3^{\text {rd }} \text { quarter of } 201 \text { and } 1^{\text {st }} \text { quarter of 2020, } \\
\text { and value of } 1 \text { between } 2^{\text {nd }} \text { quarter of } 2020 \text { and } 2^{\text {nd }} \text { quarter of } 2021 . \\
\text { - Size: Natural Logarithm of Total Assets } \\
\text { - TAT: Net Sales/Total Assets (endogenous) } \\
\text { - NPM: Net Income/Net Sales (endogenous) } \\
\text { - Debt-to-Assets: Total Liabilities/Total Assets (endogenous) }\end{array}$ \\
\hline 3 & NPM: Net Income/ Net Sales & $\begin{array}{l}\text { COVID: Dummy variable taking value } 0 \text { between } 3^{\text {rd }} \text { quarter of } 201 \text { and } 1^{\text {st }} \text { quarter of 2020, } \\
\text { and value of } 1 \text { between } 2^{\text {nd }} \text { quarter of } 2020 \text { and } 2^{\text {nd }} \text { quarter of } 2021 . \\
\text { - Size: Natural Logarithm of Total Assets } \\
\text { - Quick: (Current Assets-Inventories)/Current Liabilities } \\
\text { - GPM: Gross Profits/ Net Sales (endogenous) } \\
\text { - Debt-to-Equity: Total Liabilities/Total Assets (endogenous) }\end{array}$ \\
\hline
\end{tabular}

The correlation table of the variables used in models are also provided as follows, showing that there is no significant correlation between variables used in the same single model.

Table 2: Correlation Matrix of the Variables

\begin{tabular}{|c|c|c|c|c|c|c|c|c|c|c|}
\hline & Quick & TAT & D-E & EM & D-A & GPM & NPM & ROA & ROE & Size \\
\hline Quick & 1 & & & & & & & & & \\
\hline TAT & $-0,1495$ & 1 & & & & & & & & \\
\hline D-E & $-0,0307$ & 0,0483 & 1 & & & & & & & \\
\hline EM & $-0,0307$ & 0,0483 & 1 & 1 & & & & & & \\
\hline D-A & $-0,3549$ & 0,2684 & 0,0605 & 0,0605 & 1 & & & & & \\
\hline GPM & 0,0879 & $-0,034$ & 0,0075 & 0,0075 & $-0,0341$ & 1 & & & & \\
\hline NPM & 0,0144 & $-0,032$ & $-0,0053$ & $-0,0053$ & $-0,0584$ & 0,1102 & 1 & & & \\
\hline ROA & 0,2325 & 0,062 & $-0,0227$ & $-0,0227$ & $-0,4606$ & 0,3281 & 0,1145 & 1 & & \\
\hline ROE & 0,0231 & $-0,0053$ & $-0,7462$ & $-0,7462$ & $-0,0298$ & 0,0763 & 0,0701 & 0,1308 & 1 & \\
\hline Size & $-0,0994$ & 0,0403 & 0,0478 & 0,0478 & 0,1354 & 0,1127 & 0,0043 & 0,1385 & 0,0303 & 1 \\
\hline
\end{tabular}

\section{FINDINGS}

Models are first tested in sample of all firms, then sample is splitted into manufacturing firms and non-manufacturing firms to be able to compare effects of COVID in different industries. Sargan test of overidentifying restrictions have insignificant $p$-values in all models, meaning overidentifying restrictions are valid. Moreover, Arellano-Bond test for zero autocorrelation in first-differenced errors show there are no autocorrelation problems at second order. Results of these two tests support the use of Arellano-Bond dynamic panel-data estimation to analyse our models.

Table 3 reports the findings of Model 1, where ROE is dependent variable. First of all, persistence of ROE can be observed from the significant coefficient of lagged ROE in all samples. In sample of all firms, ROE is found to be affected positively in COVID period. But when we split the sample into manufacturing and non-manufacturing firms, ROE of manufacturing firms are found to be influenced in a negative way, whereas

\footnotetext{
${ }^{1}$ Du Pont Formula: ROA = Net profit margin $x$ Total asset turnover Modified Du Pont Formula: ROE = ROA x Financial Leverage Multiplier (Equity Multiplier) Reference: Gitman\&Zutter (2015)
} 
ROE of non-manufacturing firms are influenced positively. In all three samples size variable has positive significant effect on ROE. TAT and NPM also have significant positive effects on ROE, but EM which represents financial leverage, has a negative effect on ROE. In manufacturing firms, ROE is mostly influenced by size, in non-manufacturing firms TAT is the variable with the highest coefficient. It shows the importance of asset management efficiency for non-manufacturing firms during turbulent time periods.

Table 3: Findings of Model 1 (Dependent Variable: ROE)

\begin{tabular}{|c|c|c|c|c|c|c|c|c|c|}
\hline \multicolumn{10}{|c|}{ Dependent Variable: ROE } \\
\hline & \multicolumn{3}{|c|}{ All Firms } & \multicolumn{3}{|c|}{ Manufacturing Firms } & \multicolumn{3}{|c|}{ Non-manufacturing Firms } \\
\hline & Coeff. & Std.Error & p-Value & Coef. & Std.Error & p-Value & Coeff. & Std.Error & p-Value \\
\hline $\mathrm{ROE}_{\mathrm{t}-1}$ & $-0,0109$ & $1,28 \mathrm{e}-06$ & 0,000 & 0,0003 & $3,76 e-06$ & 0,000 & $-0,0204$ & 0,0000114 & 0,000 \\
\hline TAT & 1,4571 & 0,0000887 & 0,000 & 0,0982 & 0,0002443 & 0,000 & 1,8998 & 0,0028907 & 0,000 \\
\hline NPM & 0,2447 & $9,86 e-06$ & 0,000 & 0,1954 & 0,0004024 & 0,000 & 0,1661 & 0,0001339 & 0,000 \\
\hline EM & $-0,0686$ & $5,83 e-07$ & 0,000 & $-0,1178$ & $1,35 \mathrm{e}-06$ & 0,000 & $-0,0616$ & $9,75 e-06$ & 0,000 \\
\hline COVID & 0,3455 & 0,000163 & 0,000 & $-0,0279$ & 0,0001479 & 0,000 & 0,6704 & 0,0014945 & 0,000 \\
\hline Size & 1,2426 & 0,00025 & 0,000 & 0,5515 & 0,0004008 & 0,000 & 1,1171 & 0,0045633 & 0,000 \\
\hline \multirow[t]{2}{*}{ Constant } & $-17,913$ & 0,0563 & 0,000 & $-6,9735$ & 0,0203 & 0,000 & $-17,2893$ & 0,1563 & 0,000 \\
\hline & \multicolumn{3}{|c|}{$\begin{array}{l}\text { Wald Statistics } p \text {-value: } 0.000 \\
\text { Sargan test statistics } p \text { value: } 0.2794 \\
\text { AR(1) p-value: } 0.4206 \\
\text { AR(2) p-value: } 0.3792\end{array}$} & \multicolumn{3}{|c|}{$\begin{array}{l}\text { Wald Statistics } p \text {-value: } 0.000 \\
\text { Sargan test statistics } p \text { value:0.9989 } \\
\text { AR(1) p-value: } 0.0169 \\
\text { AR(2) p-value: } 0.6008\end{array}$} & \multicolumn{3}{|c|}{$\begin{array}{l}\text { Wald Statistics } p \text {-value: } 0.000 \\
\text { Sargan test statistics p value: } 1.000 \\
A R(1) p \text {-value: } 0.3695 \\
A R(2) p \text {-value: } 0.1717\end{array}$} \\
\hline
\end{tabular}

The findings of Model 2 (dependent variable:ROA) are provided in Table 4 below. Again lagged dependent variable is found to be statistically significant showing the persistence of profitability on assets. According to the findings, COVID seems to have a negative effect on ROA of both manufacturing and non-manufacturing firms, but this negative effect is not so high compared to negative effect of Debt-to-assets ratio especially for non-manufacturing firms. Size and Net Profit Margin variables are found to have significant positive effects on ROA in all three samples. Moreover, TAT affects ROA of the manufacturing firms positively but it has a negative effect on ROA of non-manufacturing firms.

Table 4: Findings of Model 2 (Dependent Variable: ROA)

\begin{tabular}{|c|c|c|c|c|c|c|c|c|c|}
\hline \multicolumn{10}{|c|}{ Dependent Variable: ROA } \\
\hline & \multicolumn{3}{|c|}{ All Firms } & \multicolumn{3}{|c|}{ Manufacturing Firms } & \multicolumn{3}{|c|}{ Non-manufacturing Firms } \\
\hline & Coeff. & Std.Error & p-Value & Coef. & Std.Error & p-Value & Coeff. & Std.Error & p-Value \\
\hline $\mathrm{ROA}_{\mathrm{t}-1}$ & 0,4596582 & 0,0001702 & 0,000 & 0,4157075 & 0,0003911 & 0,000 & 0,2777868 & 0,0021358 & 0,000 \\
\hline TAT & 0,0686652 & 0,0002834 & 0,000 & 0,0781033 & 0,0005157 & 0,000 & $-0,0297588$ & 0,0024914 & 0,000 \\
\hline NPM & 0,0000703 & $1,66 \mathrm{e}-07$ & 0,000 & 0,0603248 & 0,0000704 & 0,000 & 0,0015142 & 0,0000212 & 0,000 \\
\hline DTOASSETS & $-0,2287836$ & 0,0005438 & 0,000 & 0,0000972 & $2,35 e-06$ & 0,000 & $-1,290122$ & 0,0061268 & 0,000 \\
\hline COVID & $-0,0465217$ & 0,0002529 & 0,000 & $-0,0323057$ & 0,0002861 & 0,000 & $-0,0260019$ & 0,0018052 & 0,000 \\
\hline \multirow[t]{2}{*}{ Size } & 0,1734979 & 0,0002798 & 0,000 & 0,1772763 & 0,000443 & 0,000 & 0,0799663 & 0,0042204 & 0,000 \\
\hline & \multicolumn{3}{|c|}{$\begin{array}{l}\text { Wald Statistics } p \text {-value: } 0.000 \\
\text { Sargan test statistics } p \text { value: } 0.3063 \\
\text { AR(1) p-value: } 0.1024 \\
A R(2) p \text {-value: } 0.6816\end{array}$} & \multicolumn{3}{|c|}{$\begin{array}{l}\text { Wald Statistics } p \text {-value: } 0.000 \\
\text { Sargan test statistics p value:0.9988 } \\
\text { AR(1) p-value: } 0.2306 \\
\text { AR(2) p-value: } 0.4722\end{array}$} & \multicolumn{3}{|c|}{$\begin{array}{l}\text { Wald Statistics } p \text {-value: } 0.000 \\
\text { Sargan test statistics p value: } 1.000 \\
\text { AR(1) p-value: } 0.2110 \\
A R(2) \text { p-value: } 0.2224\end{array}$} \\
\hline
\end{tabular}

In the third model, dependent variable is NPM and its findings are summarized in Table 5 below. Persistence of net profit margin can be observed from the significance of the lagged dependent variable in all samples. The results show that COVID-19 has a negative effect on NPM in all firms sample. However, splitting the sample into two reveals that NPM of manufacturing firms are affected positively, despite NPM of non-manufacturing firms are affected negatively during pandemic period. This finding suggest that lockdowns during the pandemic period made it difficult to manage the costs for non-manufacturing firms. Although manufacturing firms were able to continue their operations during lockdowns, it was impossible especially for service industry and it is reflected negatively on NPM of non-manufacturing firms.

Table 5: Findings of Model 3 (Dependent Variable: NPM)

\begin{tabular}{|c|c|c|c|c|c|c|c|c|c|}
\hline \multicolumn{10}{|c|}{ Dependent Variable: NPM } \\
\hline & \multicolumn{3}{|c|}{ All Firms } & \multicolumn{3}{|c|}{ Manufacturing Firms } & \multicolumn{3}{|c|}{ Non-manufacturing Firms } \\
\hline & Coeff. & Std.Error & p-Value & Coef. & Std.Error & p-Value & Coeff. & Std.Error & p-Value \\
\hline NPMt-1 & 0.5166883 & $6.34 \mathrm{e}-06$ & 0.000 & 0.3782034 & 0.000016 & 0.000 & 0.5207707 & 0.0005304 & 0.000 \\
\hline QUICK & -1.671978 & 0.0001443 & 0.000 & -0.0413601 & 0.0002341 & 0.000 & -1.079649 & 0.0159058 & 0.000 \\
\hline GPM & 3.778839 & 0.0001545 & 0.000 & 0.471759 & 0.0001426 & 0.000 & 4.355832 & 0.0088333 & 0.000 \\
\hline DTOE & -0.0012224 & $9.55 e-06$ & 0.000 & 0.0001543 & $2.03 e-06$ & 0.000 & -0.0002504 & 0.0000127 & 0.000 \\
\hline COVID & -0.6022564 & 0.0006316 & 0.000 & 0.0667859 & 0.0004095 & 0.000 & -0.8387628 & 0.0155558 & 0.000 \\
\hline Size & 4.021243 & 0.0010023 & 0.000 & -0.0452228 & 0.0003432 & 0.000 & 5.964334 & 0.0236981 & 0.000 \\
\hline Constant & -52.0664 & 0.1351 & 0.000 & 0.5668 & 0.0047 & 0.000 & -81.0052 & 0.6423 & 0.000 \\
\hline
\end{tabular}




\begin{tabular}{|l|l|l|l|}
\hline & Wald Statistics $p$-value: 0.000 & Wald Statistics $p$-value: 0.000 & Wald Statistics $p$-value: 0.000 \\
& Sargan test statistics $p$ value:0.2975 & Sargan test statistics $p$ value:0.9988 & Sargan test statistics $p$ value:1.000 \\
& $A R(1) p$-value: 0.4206, & $A R(1) p$-value: 0.2723 & $A R(1) p$-value: 0.1923 \\
& $A R(2) p$-value: 0.3792 & $A R(2) p$-value: 0.4722 & $A R(2) p$-value: 0.6964 \\
\hline
\end{tabular}

\section{CONCLUSION}

The results of the dynamic panel data analysis in this study show that COVID-19 pandemic has both negative and positive effects on profitability ratios of listed firms in Turkey. Return on Asset ratios of all firms, both in manufacturing and non-manufacturing industries have been affected negatively, but this effect is rather a slight effect. Findings about Return on Equity and Net Profit Margin ratios are mixed.Even though non-manufacturing firms' ROE ratios have been influenced positively in COVID period, their Net Profit Margins have been affected negatively and the effects are vice versa for manufacturing firms. Negative effect on non-manufacturing firms' NPMs is most probably the effects of lockdowns and restrictions imposed during COVID period. Although manufacturing firms were able to continue their operations, it was not possible for most of the non-manufacturing firms especially in service industry. Despite the negative effect on NPM of nonmanufacturing firms, ROE is found to be affected positively, which may be an indication that these firms were better at using their equity in an efficient way. According to Du Pont Identity ROE is a product of NPM, TAT and EM. We do not know the effects of COVID on TAT and EM. Thus, together with the effects of COVID on TAT and EM, ROE seems to be affected positively in non-manufacturing firms.Despite the negative effect on ROE of manufacturing firms, NPM is found to be affected positively, which may be an indication that these firms were better at managing their costs and operations efficiently. But again we don't know the effects of COVID on TAT and EM and together with the effects of COVID on TAT and EM, ROE seems to be affected negatively in manufacturing firms.

In future studies, impact of COVID-19 on Total Asset Turnover and leverage ratios may be analysed, so that effects on profitability may be explained more comprehensively. Also, market-based performance measures may be used as dependent variable. Additionally, macroeconomic variables such as Consumer Price Index and Gross Domestic Product may be considered as control variables in regression models.

\section{REFERENCES}

Amnim, O. E., C.Aipma, O. P., \& Fabian, C. (2021). Impact of Covid-19 Pandemic on Liquidity and Profitability of Firms in Nigeria. International Journal of Academic Research in Business and Social Sciences, 11(3), 1331-1344.

Ashraf, B. N. (2020). Economic impact of government interventions during the COVID-19 pandemic: International evidence from financial markets. Journal of Behavioral and Experimental Finance.

Bulut, O. M., \& Gurbuz, O. (2021). Salgın Sürecinde Kurumsal Yönetim Endeksinde Yer Alan Şirketlerin Performansı. TURAN-SAM Uluslararası Bilimsel Hakemli Dergisi, 219-233.

Can, O. (2021). Covid-19 Salgınının Türkiye'deki İşletmelere Etkileri: Sorunlar, Dönüşümler, Olanaklar. Ataturk Universitesi, IIBF Dergisi, 35(3), 833-863.

Canli, S. N., \& Ozdemir, M. (2021). Determining the Financial Impacts of Covid-19 Pandemic: An Application on Turkish Airlines Industry. Third Sector Social Economic Review, 56(2), 657-681.

Dagli, D. (2021). Havayolu İşletmelerinin Covid-19 Öncesi ve Covid-19 Sürecindeki Finansal Performanslarının TOPSIS Yöntemi ile Değerlendirilmesi. İşletme Araştırmaları Dergisi, 13(3), 2242-2255.

Devi, S., Warasniasih, N. M., Masdiantini, P. R., \& Musmini, L. S. (2020). The Impact of COVID-19 Pandemic on the Financial Performance of Firms on the Indonesia Stock Exchange. Journal of Economics, Business, and Accountancy Ventura, 23(2), $226-242$.

Durak, İ., \& Çömlekçi, İ. (2021). BIST100 Endeksinde Yer Alan Firmaların COVID-19 Öncesi ve COVID-19 Dönemi Finansal Verilerine Göre Sınıflandırılması: Bir Hiyerarşik Kümeleme Analizi Uygulaması. Journal of Yasar University,, 16(64), 1657-1681.

Gourinchas, P.-O., Kalemli-Özcan, Ș., Penciakova, V., \& Sander, N. (2021). COVID-19 and SME Failures. Cambridge: National Bureau of Economic Research.

Hu, S., \& Zhang, Y. (2021). COVID-19 pandemic and firm performance: Cross-country evidence. International Review of Economics \& Finance, 74, 365-372.

Khatib, S. F., \& Nour, A.-N. I. (2021). The Impact of Corporate Governance on Firm Performance During The COVID-19 Pandemic: Evidence from Malaysia. Journal of Asian Finance, Economics and Business, 8(2), $0943-0952$.

Kilinc, F., \& Calis, E. (2021). The Effect of the Covid-19 Pandemic on the Food Industry And The Relationship With Financial Performance. Research of Financial Economic and Social Studie, 6(3), 499-508.

Kutay, N., \& Tektufekci, F. (2021). Examination of the Impact Of Covid-19 Epidemıc on Borsa Istanbul Tourism Index Enterprises' Financial Statements And Independent Auditor's Reports With A Holistic Approach. International Journal of Contemporary Tourism Research, Special Issue, 73-97 
Ozcan, M. (2021). COVID 19 Pandemisinin Turizm ve Ulaştırma İşletmelerinin Finansal Performansına Etkisi. Uluslararası Toplum Araştırmaları Dergisi, 11(17), 3542-3567.

Song, H. J., Yeon, J., \& Lee, S. (2021). Impact of the COVID-19 pandemic: Evidence from the U.S. restaurant industry. International Journal of Hospitality Management, 92

Sun, T., Zhang, W.-W., Dinca, M. S., \& Raza, M. (2021). Determining the impact of Covid-19 on the business norms and performance of SMEs in China. Economic Research-Ekonomska Istraživanja.

Yücel, S., \& Durak, İ. (2021). Investigation of Financial Impacts of COVID-19 on BIST Manufacturing Sector Firms by Financial Ratios and Statistical Techniques. The Journal of Accounting and Finance, 90, 101-126.

ZhaominRen, XuanZhang, \& ZhekaiZhang. (2021). New evidence on COVID-19 and firm performance. Economic Analysis and Policy, 72, 213225. 